\title{
Hedging Against China: Japanese Strategy Towards A Rising Power
}

\section{Ll. López i Vidal and Àngels Pelegrín}

For more than fifty years, Japan's foreign policy was strongly marked by its defeat by the allied powers in World War II and the beginning of Cold War bipolarity. In addition to becoming an economic superpower and establishing constitutional pacifism as the bedrock of its political system, Japan also became an 'outstanding partner' for the United States. This formula - the so-called Yoshida doctrine - permitted Japan to focus on economic growth and wealth, leaving security matters to the United States. Despite the anomaly that Japan represented during this period of bipolarity, its strategy allowed the country to achieve security and prosperity. However, the Yoshida doctrine was not designed for the uncertain post-Cold War order.

Following almost five decades of occupying this "abnormal" place on the world stage, Japan entered a new period in which new challenges have arisen as a consequence of changes in both the international and domestic systems. For Japan, the demise of the bipolar system meant that the Soviet Union was no longer the most significant threat to its security. At the same time, the collapse of the political party system in 1993 had a major impact on Japan's institutional framework, facilitating a more pro-active and assertive global profile. In post-Cold War Japan, therefore, the country's main concerns can be said to be the fear of abandonment and entrapment by the United States, the relative decline of its economy, the ongoing threats posed by North Korea to Japanese territory, and, last but not least, the uncertain rise of China.

In particular, the re-emergence of China as a regional and global power has become an issue of special concern in a period of multi-polarity and power transition and Japan's strategy towards the rise of China in the post-Cold War period is significant for several reasons. First of all, although Japan is not the main player that has to deal with the systemic issue of the rise of China, the Japanese reaction to the re-emergence of China will be an essential factor in determining the balance of power in East Asia. The two countries are the most powerful actors in this region and their strategies towards each other have regional and global consequences for the balance of power. In world history, China - as a rising power - and Japan - as a declining 
power - have never before shared equal power status at the same time and, so, like two large carps in a small pond, they must confront each other in troubled waters. Secondly, Japan remains the US's most important ally in the Asia-Pacific region and, as such, Japan's response to China's rise has a great impact not only on the US-Japan alliance but also on US strategy vis-à-vis the rise of China. Thirdly, Japan and China have great mutual economic interests, both in terms of trade and investment, and their economic interdependence has grown in recent decades, with obvious consequences for regional and global economies. Lastly, Japan has to devise a China strategy consistent with its overall foreign policy for the 21 st century: a course that is coherent with what has been described as the "normalization" of Japanese diplomacy. In order to find its place in the world, Japan must decide how to deal with China's rise. ${ }^{1}$ This onerous task means charting the right course between a declining United States and the uncertain emergence of China.

Assuming that Japan can be considered a 'middle power', from the 1990s onwards it can be seen to have been pursuing a "hedging" strategy in its relations with Beijing. Although China probably represents the greatest potential military threat to Japan, in order to avoid tensions between the two, it has not been officially recognized as such. Japan is not balancing against China, but neither is it bandwagoning with it or taking a neutral stance to the rise of China. If Japan were a superpower with hegemonic ambitions, Tokyo would no doubt have pursued a pure balancing strategy. However, it has followed a middle course, adopting a hedging strategy coherent with its middle-power status.

The central argument of this article is that Japan has pursued a hedging strategy during the post-Cold War era (1995-2016), which is best analyzed in terms of Kuik's ${ }^{2}$ understanding of hedging, rather than by applying alternative interpretations of the concept. ${ }^{3}$ This article therefore provides an insight into the conceptualization of hedging as a strategy in International Relations (IR). Although a considerable number of studies have examined the rise of China and the reaction of other states to it, very few studies to date have sought to do so by applying the concept of hedging from IR theory and security studies in a systematic, coherent and rigorous fashion. There is a tendency in the literature to consider recent changes in Japan's security policy as a desire to become a militaristic power or even as a return to Japan's pre-war 
regime. However, as this article demonstrates, after the Cold War Japan is an abnormal middle power that seeks to normalize its position in the international system in line with its economic and diplomatic weight.

This study is divided into four sections. Following on from this introduction, the second section outlines the different approaches offered by IR theorists regarding the way in which countries might behave towards a rising power. It is widely held that states either balance against a rising power or bandwagon with it; yet, as this article shows, an array of alternatives arise if we do not limit ourselves solely to these two mainstream schools in IR. Given the theoretical limitations, this article proposes an appropriate framework in which to analyze Japan's China policy, adapting Kuik's hedging concept to the case of Japan. In the third section of the article, we examine the recent evolution in Japan's policy towards China in the postCold War era and describe how Japan's strategy has shifted away from "friendship diplomacy" towards a new paradigm that is better described in terms of the hedging concept. In the fourth section, we apply this hedging framework to the recent evolution in Japanese foreign policy in order to determine whether Kuik's framework fits the Japanese case. In the final section we draw our conclusions and offer some final remarks.

\section{International Relations Theory and Rising Powers}

IR theory provides an array of competing perspectives and paradigms that are generally regarded as mutually exclusive. In the middle of this heated paradigmatic debate, it is crucial to observe how the literature has sought to explain the behavior of states in periods of power transition. The leading voice of offensive realism is that of John J. Mearsheimer, who, in The Tragedy of Great Power Politics (2001), analyses how great powers behave and why they decide to go to war. One of Mearsheimer's main assumption is that state's intentions can be benign one day and hostile the next, therefore no state can be sure whether or not another state will initiate an aggression. ${ }^{4}$ Accordingly, survival is the primary goal of any power and the "lust for power" causes states to compete with each other to maximize their share of it.

Whereas all states have revisionist intentions and there are no status quo powers in the 
international system, it is highly unlikely that a state will attain global hegemony. ${ }^{5}$ Thus, the world is condemned to "perpetual great-power competition", which is a cruel and no less pessimistic description of the world. ${ }^{6}$ An additional assumption is that states are rational actors behaving in an anarchic world, and they are inclined to behave strategically when it comes to survival. When the costs of altering the balance of power are too high, states tend to bide their time until the risks are not so great.

In seeking to respond to the question as to how states react to a rising power, Mearsheimer identifies four possible strategies: bandwagoning, appeasement, balancing and buck-passing. The first strategy involves joining forces with a more powerful opponent in the hope of sharing some of the benefits with the ascendant power. Nevertheless, betting on the "surefire winner" in the hope of obtaining economic benefits is clearly a strategy for the weak. In the case of the second strategy, appeasement, Mearsheimer claims that states choose this approach so that they can "push the aggressor in a more pacific direction and turn it into a status quo power". ${ }^{7}$ Considering that states react to hegemonic powers as they feel "vulnerable", this strategy seeks to downsize that sense of insecurity and, consequently, the reasons for possible aggression.

However, in the real world, states tend to consider the worst-case scenario and so adopt a balancing strategy, which can take the form of either internal or external balancing. When states balance internally, they seek to increase their own military capabilities to counter the rising power; when they do so externally, they seek alliances with other states to balance against a threatening state. Lastly, states adopting the buck-passing strategy seek to transfer the burden of deterring or attacking a rising power. States are quite likely to adopt this strategy in multipolar systems and highly unlikely to do so in bipolar systems.

Unlike realists, liberals and constructivists consider the international system as being governed by a set of rules and agreements. The absence of a central government in the international system far from impeding cooperation actually facilitates stability. Consequently, order does not emerge from the balance of power, but rather from different levels of government made up of institutions, laws, agreements, standards and norms. Yet, how do weaker states deal with a rising power? According to liberals, weaker powers tend to cooperate 
with stronger states and to induce favorable intentions by promoting economic relations and by including rising powers in international institutions. Constructivists believe a peaceful rise is possible, but it must be a two-way process, in which the rising power accommodates itself to the rules and structures of international society. ${ }^{8}$

However, none of these theories seems to offer plausible explanations for Japan's reaction to China's rise. Contrary to what many realists suggest, ${ }^{9}$ Japan is not becoming a great military power. Even though Japan has the capacity to become a nuclear power and could change its military doctrine of "defensive defense" to one of "offensive defense", it has chosen not to develop its capabilities in an offensive way. Constitutional limitations ${ }^{10}$ and Japanese anti-militarism do not make the country's remilitarization impossible; however, it is highly unlikely. According to an opinion poll conducted by Yomiuri Shimbun in 2014, 60 percent of public opinion is against making changes to Article 9, compared with 46.7 percent in $2004 .{ }^{11}$ As Midford states, no other second-ranked economic power has preserved such a limited defense capability in recent world history. ${ }^{12}$

Japan is not powerful enough to deal with the systemic problem of China's rise alone and must rely on the United States to handle the question of power transition. At the global level, the United States is the only superpower capable of dealing with the rise of China on its own. Yet, at the regional level it needs Japan when dealing with China, since middle powers remain essential to great powers to help reduce regional security dilemmas within an uncertain multi-polar system. ${ }^{13}$ Finally, if we consider Japan as being a middle power, such states do not adopt pure forms of balancing or bandwagoning, ${ }^{14}$ but rather a mixed strategy. This is what we analyze in the following section.

\section{Hedging as an answer to rising powers}

As we shall see below in section 3, the empirical evidence indicates that Japan, contrary to realist arguments, is willing neither to balance against Chinese power nor to bandwagon with it. Moreover, neither is Japan pursuing what liberals suggest should be the normal path: 
economically engaging China in order to benefit from trade and investment with the rising power. Recent trends in Chinese-Japanese relations show how, despite their mutual economic interdependence, neither country is adhering to a purely cooperative strategy but rather that they have adopted elements of a hedging strategy too. In short, Japan currently adheres to a mixed strategy, described by various authors as a hedging strategy. ${ }^{15}$ Yet, most of these studies do not examine the theoretical concept in any great depth and apply it in a very broad sense, with a meaning that ranges from simple engagement to more complex counterbalancing policies.

One of the first authors to speak of hedging in this context was Denny Roy, whose coining of the term provides us with a good starting point for our discussion. Roy argues that in facing a potential regional hegemon, states have four choices: balancing, bandwagoning, engagement or hedging. Accordingly, states adopt a hedging strategy (which may or may not include balancing) when there is a high degree of uncertainty about a rising power's real intentions. As such, hedging is understood as a general strategy that entails "keeping open more than one strategic option against the possibility of a future security threat." ${ }^{16}$ While it is true that Roy does not develop the concept theoretically and does not propose a model applicable to middle powers, he does contribute one fundamental idea: in the international arena, risks and imminent threats determine when a state must decide whether to accept, accommodate or reject a given rising power. Mearsheimer claims that when a state perceives an imminent threat, it balances, bandwagons or adopts other intermediate strategies, such as appeasement or buckpassing. However, what happens when the threat is not so obviously imminent? In such circumstances, Roy suggests that powers tend to hedge.

Jeffrey Hornung has recently undertaken an analysis of Japan's response to the rise of China by employing a spectrum of strategies that ranges from pure balancing to pure engagement at the two ends of a continuum. ${ }^{17}$ Between these two extremes, he locates the strategy of both soft and hard hedging. For Hornung, a soft hedge involves fostering cooperatives policies with the rising power, including the promotion of diplomatic and economic ties. In contrast, a hard hedge involves adopting a set of strategies more similar in 
nature to balancing, including the beefing up of one's defensive capabilities or the forging of alliances with other powers.

Although Hornung undertakes a highly systematic analysis of Japanese strategy vis-àvis China and illustrates how Japan is employing policies that combine elements of both engagement and balancing, his framework of enquiry presents three weaknesses. Firstly, he considers engagement, not balancing, as the opposite strategy to that of bandwagoning, arguing that the former depends on cooperative policies and the promise of rewards, as opposed to the use of force. For the author, bandwagoning is the strategy of weak states. However, the term bandwagoning has been used elsewhere not only to mean aligning oneself with the most powerful ally in order to avoid being attacked, ${ }^{18}$ but also as a way to obtain gains and rewards from allying with the most powerful state. ${ }^{19}$ Thus, bandwagoning constitutes an option for weaker states, which want to offset the risk of being attacked, and an engagement strategy for middle powers, which view an alliance as a positive-sum game.

Secondly, for Hornung, hedging does not constitute a set of multiple options that can be employed simultaneously. Although the author identifies hedging as a strategy that combines elements of both engagement and balancing, in his analysis of Japan's strategy, the term, and its different degrees (both hard and soft), is ultimately used as a synonym of balancing. Hornung does not employ the term hedging as an intermediate strategy that might simultaneously include a mix of tools of cooperation and containment; rather, hedging is understood as a form of engagement or balancing, or at the most, a binding mechanism, and not as a complex and systematic concept.

Finally, the notions of "uncertainty" and "risk" are treated in Hornung in line with realist tenets, that is, understanding them in political or military terms. However, a distinction needs to be drawn between imminent and non-imminent risks. When a country such as Japan faces no imminent threats, it tends to hedge. However, what occurs when a country faces a direct threat? In such circumstances, countries do not adopt an engagement policy but a pure balancing or bandwagoning strategy.

Kuik provides one of the first systematic theoretical analyses of hedging behavior in 
IR. According to the author, the concept of hedging refers to "a behavior in which a country seeks to offset risks by pursuing multiple policy options that are intended to produce mutually counteracting effects, under the situation of high uncertainties and high stakes". ${ }^{20}$ In common with Mearsheimer and Roy, Kuik reminds us that in the realm of international politics, risks and imminent threats are what make states accept, accommodate or reject a particular rising power. When a state perceives a rising power as an imminent security threat, it will pursue a balancing strategy vis-à-vis the actor; in contrast, when a state views an actor as a principal source of aid, then it is likely to opt for bandwagoning. Yet, what occurs when a state does not perceive any imminent or obvious threat? When states are unable to develop overly close or overly distant relations with a major power or when they are unsure as to which bandwagon they should "jump" on, they have a tendency to hedge. Hedging is a strategy that "aims for the best and prepares for the worst". ${ }^{21}$

\section{Table 1: Hedging Strategies in Response to the Rise of a Great Power, According to}

\section{Kuik}

Kuik considers hedging as constituting a set of policies that simultaneously pursue counteractions aimed at maximizing options and avoiding risks. On the one hand, there are the return-maximizing options, which include economic-pragmatism, binding-engagement and limited- bandwagoning. The term economic-pragmatism is defined in Kuik as an attempt to maximize gains from a rising power through the establishment of direct trade and investment links, in spite of any political or security concerns that might exist between the two. The middle power, without accepting or denying the political authority of the rising power, regards the latter as an economic power that provides it with economic opportunities.

The concept of binding-engagement refers to the situation in which a middle power decides to establish formal contacts with a rising power in the hope of creating channels of communication and of socializing the power into the established order, with the ultimate goal of influencing the power's policy choices. The middle power seeks to ensure that the rising 
power forms part of the international community, adheres to status-quo norms and is a responsible stakeholder thereof.

Other states adopt a limited-bandwagoning approach to the rising power, which consists of forming a political partnership in order to obtain present or future rewards from it, without losing any autonomy or eroding its current relationship with any other dominant power.

On the other hand, there are various risk-contingency options that entail indirectbalancing and dominance-denial. Dominance-denial is adopted when a country seeks to prevent or deny the emergence of a rising power in a region where it might pose a challenge to the status quo. Two actions can contribute to this process: the involvement of other powers in regional affairs and the development of its own diplomatic and security tools. While bindingengagement aims at engaging the rising power in a region, dominance-denial seeks to prevent its dominance and any hegemonic desire it might entertain.

Finally, indirect-balancing involves balancing militarily (both internally and externally) the uncertain power of a rising state, without specifically recognizing that it constitutes a military threat. By adopting this strategy, a middle power seeks to forge an alliance with other powers, while at the same time modernizing its defense capabilities but without specifically targeting the rising power. While pure balancing strategies represent a clear-cut military policy of containment against a specific threat, an indirect balancing strategy sees a state acting in case an uncertain situation arises.

Although Kuik uses his hedging model to account for the behavior of small states (primarily in South-East Asia) in the face of a rising power, it is our firm contention that this same concept can be used to explain the behavior of a middle power like Japan. To identify a middle-power state, the most traditional approach is to aggregate material criteria and to rank economic capabilities. ${ }^{22}$ However, this approach overlooks a very important quality of any middle-power state, namely, its behavioral attributes. Jordaan ${ }^{23}$ offers a more complete characterization that sees a middle power as an actor that is stable, wealthy and democratic, and which employs a foreign policy centered on the taking of multilateral initiatives. Moreover, a middle power seeks to be a stabilizer of the current global order and does not attempt to 
jeopardize it.

In analyzing the concept of 'middle power' as applied to Japan, the most frequently adopted definition is that proposed by Yoshihide Soeya. ${ }^{24}$ Thus, the chief characteristics of Japan as a middle power are its 1) commitment to multilateralism;2) the high degree of civil society participation that occurs in its foreign policy; and, 3) a national identity inextricably tied to peacekeeping activities, human security and comprehensive security.

This definition is very much in line with our own understanding of a middle power and facilitates our understanding of Japan's current role in the international community. Japan is neither a small nor a great power. Although it has the capacity to become a great power, since 1945 it has opted not to take this path and to concentrate instead on its middle-power profile on the international stage. In spite of Shinzo Abe's recent measures in the realm of security, Japan continues to adhere to a diplomacy that is committed to multilateralism, peacekeeping operations and limited participation in security activities.

\section{Japan's Policy Towards China}

In order to understand recent changes in Japan's policy towards China and to comprehend its current hedging strategy, in this section we outline the policy evolution from two perspectives: first, in terms of Japan's political and security relationship with China from the 1970s down to the present day and, second, in terms of their economic relationship over the last forty years. In so doing, we consider not only Japan's strategy as two faces of the same coin, but we also identify the distinct paradigms adopted by Japan during the Cold and post-Cold War periods.

\section{Politics and security}

The basic framework of relations between Japan and China lie in the 1972 Sino-Japanese Communiqué and the 1978 Treaty of Peace and Friendship, which normalized diplomatic relations between the two countries and ushered in almost twenty years of uninterrupted cooperation - a period referred to by both parties as an "era of unprecedented friendship". In line with a policy of seikei bunri, that is, the separation of economics and politics, China and 
Japan began to promote mutual trade deals. ${ }^{25}$ It was no coincidence that in 1979 the Japanese government launched its first package of Official Development Assistance (comprising loans, grant aid, and technical cooperation) aimed at promoting stability and growth in China. ${ }^{26}$ This assistance program represented a form of compensation for the damage inflicted on the Chinese people, but Tokyo was very much of the opinion that a prosperous China would make a good friend.

However, in this period characterized by the so-called "friendship diplomacy", a certain amount of friction was evident in the relations between the two countries. The main disputes centered on Japan's military past and controversies concerning the so-called rekishi ninshiki (recognition of history), and the Taiwan question. In relation to this first conflict, although Japan officially expressed its deep remorse (fukaku hansei) in the preamble to the 1972 SinoJapanese Joint Communiqué and later issued an apology (owabi) for its aggressive past, the situation was soured by the Japanese school textbook controversy in the early 1980 s. $^{27}$

In 1982, the media reported that the Japanese Ministry of Education had introduced changes in a history textbook describing the country's military presence in China during the 1930s and 40s not as an aggression (shinryaku) but rather as an advance into (shinshutsu) the territory. Following protests and riots in China against this historical revisionism, the Japanese government chose to introduce new guidelines. In this period of transition to a market economy, the majority of Liberal Democratic Party members undertook not to damage the relationship and to avoid destabilizing relations with China. The Japanese government announced that Tokyo had a significant role to play in helping the Chinese economic transformation. Thus, any tensions in the post-normalization process were framed in a structure that permitted both countries to ignore any matters that might give rise to immediate trouble, thereby allowing both parties to enjoy an apparent friendship. ${ }^{28}$ Conflicts, rather than being solved, were "shelved", their resolution being put off for a later date. In cultural terms, both countries were concerned about their public face (tatemae), but they did not go very far in resolving frictions and eliminating feelings of mistrust (honne).

However, it was not until the Tiananmen Square incident in June 1989 that the first cracks began to appear in the "friendship diplomacy". Although Japan imposed only light 
sanctions on China, ${ }^{29}$ several incidents strengthened the idea that "friendship diplomacy" was insufficient to persuade China to behave benignly. Since that date, various developments, above all in the security realm, have shifted Japanese perceptions about China in a negative direction.

The ongoing dispute over the Senkaku/Diaoyu Islands, the Chinese Law of the Territorial Sea of $1992,{ }^{30}$ Chinese nuclear testing (1995) and military exercises in the Taiwan Strait during the Taiwanese presidential election in 1996, the Exclusive Economic Zone (EEZ) dispute, and China's military build-up were all matters that gave the Japanese government cause for concern and cast doubts on China's rise as an emerging power in the new century. Yet, rather than adopting a pure balancing strategy, in the years following 1996 Japan initiated a mixed strategy that included elements of engagement with and moderate balancing against China's rise.

Thus, following an initial period in which Japan feared it might be abandoned by the United States, Tokyo and Washington actually strengthened their alliance in order to safeguard Japan's security and uphold regional stability. The 1996 Joint Security Declaration signed by Hashimoto and Clinton, the 1997 New Defense Cooperation Guidelines, along with undertakings to conduct joint technical research on Ballistic Missile Defense, demonstrated both parties' willingness to reaffirm the alliance. In addition, soon after this, Japan started to build up its defense system and purchased ballistic missile defense capability. China complained that Japan might use this capability in a hypothetical Taiwan-China war, with Japanese ships combining with US forces to defend Taiwan.

At the same time, a more pro-active Japanese foreign policy in the security realm, combined with US insistence that Japan should contribute to regional and international security (and so abandon its hitherto position as a free-rider), mean this alliance has become the lynchpin of US strategy in Asia. Following a period in which the US sought to rebalance its strategy, and after a shift in the center of gravity away from the Atlantic to the Asia-Pacific region, the alliance with Japan remains, in the words of Caroline Kennedy, the US Ambassador to Japan, "the cornerstone of peace, stability and prosperity in the region". 31

In the interim, North Korea has become the main official threat to Japan's security, 
particularly after the build-up of tension in 1993-1994 in response to North Korea's nuclear program and its firing in 1998 of Nodong- and Taepodong-type missiles over Japan, followed by nuclear tests conducted in 2006, 2009, and 2013. However, when it comes to China, Japan has deliberately pursued a more ambiguous strategy and rhetoric. In the 1996 Joint Security Declaration, Japan referred to China as a country with which cooperation was extremely important for reasons of regional stability and prosperity, although it left these words very much open to interpretation. Officially, Japan's deployment of its ballistic system at that time was aimed at combating North Korea's persistent threat to the country's integrity. It was not until the end of the 1990s that China and Japan began to identify each other as strategic rivals.

One of the main concerns for Japan stems from the lack of transparency in China's increasing military expenditure and the unclear intentions behind its military build-up. According to Defense of Japan 2006, China's defense expenditure might be even higher than officially reported, since no equipment procurement or research and development costs are included in official figures. Although China's military budget in 2015 was declared at around 145,900 million dollars, according to SIPRI the real expenditure is probably about 214,500 million dollars, that is, a rise of near 8 percent on the previous year. Moreover, in the last 25 years, China's military expenditure has increased more than thirty-fold, and Japan's fear is that the actual rate is much higher. Japan, on the other hand, adhered to its policy of keeping its military budget below a ceiling of 1 percent of its GDP, until Shinzo Abe came to power. In 2012, total expenditure on self-defense stood at around 60,000 million dollars, a sizeable figure for a peace-loving country. However, in practice, the amount spent on defense is higher than that reported by the Japanese government and if we estimate the expenditure in accordance with the NATO model (as employed by European countries), the amount is even greater. ${ }^{32}$ Furthermore, if we include spending on the Japanese Coast Guard, a paramilitary force created to defend its maritime zone, the final figure rises notably. ${ }^{33}$

Moreover, since the Chinese government's main security concern is maritime, its military build-up is concentrated in the naval field and Beijing is seeking to convert its fleet from a green-water into a blue-water navy with the acquisition of destroyers, submarines, and aircraft carriers. This, in part, accounts for the constant intrusion of Chinese vessels and 
warships in the EEZ in waters near to the disputed Senkaku/Diaoyu Islands and the Chunxiao gas field in the East China Sea. In 2013 the number of skirmishes involving the Chinese and Japanese naval forces intensified considerably, reaching their zenith with the unilateral declaration of the East China Sea Air Defense Identification Zone over the disputed Senkaku Island in November 2013.Despite the security issues raised by China's action for the East Asian region, Japan responded with considerable restraint to the Chinese military build-up, constant maritime activity and lack of transparency. Indeed, the National Defense Program Guidelines of 2004, 2010 and 2013 do not refer to China as a "threat", but prefer more ambiguous terms such as "concern". ${ }^{34}$ Japan considers a full-scale invasion from any country improbable and places the emphasis on new threats such as the proliferation of weapons of mass destruction and international terrorism.

After the the victory of the DPJ at the 2009 elections and despite the expectations ushered in, Japanese foreign policy has not experienced any fundamental shift away from the Yoshida Doctrine. Beyond the noise caused by clashes with the United States over the Futenma air station, and with China over the Senkaku Islands, the DPJ failed to turn most of its manifesto promises into reality. Far from developing closer strategic ties with the major Asian states such as China, Japan has not weakened its alliance with the United States, opting to strengthen defense cooperation and mutual interoperability, and at the same time Tokyo has adopted a number of decisions in the security realm in line with those of the previous Liberal Democratic administration. However, the introduction of the 2010 National Defense Program represented a shift in Japan's traditional "basic defense force" stance to a more operationally oriented "dynamic defense" posture. ${ }^{35}$

Following the election of Shinzo Abe in his landslide lower-house victory in 2012, Japanese foreign policy has undergone major changes, especially with regard to its hedging strategy. The so-called 'Abe Doctrine' is based on three main pillars: expanding Japan's defense capabilities, broadening the US-Japanese alliance, and strengthening security cooperation with third partners in the international community so that Japan can participate in certain coalitions in the security realm.

Japanese national security under the present administration embraces what Abe refers to 
as "proactive pacifism" (sekkyokuteki heiwashugi), that is, Japan is a "normal" country with the right to use military power to solve international disputes. To achieve this, and given the impossibility of amending the country's Pacifist Constitution, Abe opted for a reinterpretation of Article 9, allowing Japan to exercise its right of collective self-defense should Japan and its citizens be exposed to a clear threat and there were no other way to repel the attack other than by the use of the minimal force necessary. ${ }^{36}$

Critics claim that these new measures seek to introduce radical changes in Japanese foreign policy and that they constitute a direct balancing strategy against China. However, far from facilitating war-mongering, the new interpretation of the right to collective self-defense means that Japan's Self-Defense Forces (SDF) can come to the aid of any allies that might come under attack, especially the United States, and indirectly balance against China in the event of an imminent threat by either increasing its own capabilities or in cooperation with its allies, most notably Australia and the Philippines.

At the same time, Abe's new National Security Strategy has sought to pursue a dominance-denial option by enmeshing the likes of South Korea and Australia in some key security institutions, by transferring Japanese Coast Guard patrol ships to the Philippines, and by transferring technical skills in Coast Guard operations to Indonesia and Malaysia.

This mixed use of policy tools should be seen as a strategy to help China stabilize its economy, as well as a way of ensuring the peaceful emergence of China as a new power and of boosting the chances of success of its modernization program. Consequently, Japan's strategy vis-à-vis China has moved away from the "friendship diplomacy" of the 1970s and 1980s towards a new paradigm that combines elements of both balancing and engagement. We consider the characteristics of the economic engagement policy in the following section.

\section{Economic interdependence of Japan and China}

During the 1980s, economic relations between Japan and China were based on long-term bilateral agreements. Japanese exports to China accounted for no more than 7 percent of all its exports, while Japanese imports from China accounted for slightly less than 5 percent of all the 
country's imports. Owing to the strength of the yen, Japanese labor-intensive industries and electrical and electronic goods manufacturers opted to relocate to South-East Asia and China in search of high-quality, low-cost labor.

In the 1990s, trade became more diversified. Japan increased its imports of manufactured goods from China, especially traditional goods such as textiles, clothing and footwear. ${ }^{37}$ The volume of trade between the two countries continued to rise, climbing from 7.2 percent of total Japanese trade in 1990 to 20.9 percent in 2000. Imports of computers and other information technology products also grew, and in the case of some consumer electronic goods, such as televisions, sales of imported models outstripped those of domestic models. ${ }^{38}$ Since the beginning of this century, China became the number one supplier of imports to Japan and the latter's most important export destination, surpassing the United States. At the same time, Japan's chief investment in manufacturing in China occurred via its search for cheap labor costs and its efforts to gain a foothold in the dynamic domestic market.

When China joined the WTO (late 2001), the liberalization of its market and its rapid growth attracted large quantities of foreign capital and increased the procurement of all kinds of imports. The Chinese procurement boom ${ }^{39}$ created opportunities for Japanese exports at a time when Japanese industry was facing a stagnant domestic market. Japanese steel makers, shipbuilders, oil refineries, shippers, construction equipment manufacturers and automobile manufacturers all saw a surge in their sales to China. Most of these industries offshored plants to China in order to reduce production costs and access the large and growing local market.

Hornung ${ }^{40}$ claims that an indication of Japan's move towards a harder hedge is the reduction in its economic ties with China, specifically with regard to trade and foreign direct investment (FDI). Yet, China is Japan's largest trading partner in terms of total trade, and imports from China to Japan have grown steadily from 2000 to 2013. Exports from Japan to China also grew in 2009 and 2010 but the 2011 earthquake had a significant impact on Japan's automobile and electrical equipment industries; while exports of automobiles recovered in parallel with automobile production, exports of electrical equipment, mainly to Asia, took longer to recover. ${ }^{41}$

As a result of the earthquake, sluggish growth in China and the rapid appreciation of 16 
the yen, Japanese exports to China fell from 19.68 percent of total Japanese exports in 2011 to 18.05 percent in 2012. A similar trend can also be observed in Japanese exports to their other major partners in Asia (Korea, Taiwan, Hong Kong, Malaysia and Singapore). ${ }^{42}$ During 2013, the depreciation of the yen boosted Japanese exports. On a customs clearance basis, total exports amounted to 69.8 trillion yen, up by 9.5 percent on the previous year, and the first increase in the previous three years. Exports to Asia increased by 8.6 percent and Japan's exports to China amounted to 12.6 trillion yen, a 9.7 percent increase on the previous year. Japanese imports from China amounted to 17.7 trillion yen. As a result, Japanese trade with China accounts for 20 percent of the total of Japan's imports and exports, confirming China as Japan's largest trading partner. ${ }^{43}$

After the United States, China is the most important destination for Japanese FDI by country. According to Bank of Japan (2014) statistics, Japanese FDI in China jumped from 8.7 percent of total Japanese FDI in 2003 to 11.7 percent and 11 percent in 2011 and 2012, respectively. ${ }^{44}$ However, as Hornung ${ }^{45}$ points out, during the last period 2010-2013, there has been an acceleration of Japanese FDI into ASEAN. Table 2 shows Japan's outward FDI by country and region during the period 2009-2013. In 2011 Japan's FDI increased by 73.9 percent on the previous year, the first rise in three years; also in 2013 there was another sharp increase in Japan's FDI, partly reflecting the depreciation of the yen. ${ }^{46}$

\section{Table 2: Japanese Outward Foreign Direct Investment}

(End of manuscript)

From 2010 onwards, Japan's investment in ASEAN countries has surpassed that in China, except in 2012 as a result of the impact of the floods in Thailand. ${ }^{47}$ The hike in labor 
costs in China induced a trend towards the re-shoring of production bases from China. ${ }^{48}$ Rising wages in China have led low-end manufacturers to look for other low-cost locations for their factories in Vietnam and the Philippines.

Intra-industry and intra-firm trade between Japan and China has become increasingly dominant compared to the inter-industry trade of the early 1990s, when China mainly exported labor- and resource-intensive goods to Japan, and Japan exported capital goods to China. China's changing export pattern is clear: exports to Japan of machinery and transportation equipment jumped from 3.8 percent of total Chinese exports to Japan in 1990 to 38.3 percent in 2007. At the same time, in 2007, Japanese exports of machinery and transportation equipment accounted for 52 percent of total Japanese exports to China. ${ }^{49}$ A more detailed analysis of these patterns reveals that intra-industry trade is predominant in computers, computer parts, mobile phones and television parts. As China has emerged as one of the main destinations of Japanese FDI, intra-firm trade between Japanese parent companies and their affiliates in China has reinforced intra-industry trade between China and Japan. Leading manufacturing industries establish big plants in China, which are followed by parts and component manufacturers.

The increase in imports from China and the massive FDI flows to China intensified the need for industrial adjustment, as a number of industries lost competitiveness in the Japanese domestic market. The perception of China as an economic threat increased, and China was blamed for export deflation because of its low export prices, the undervalued Chinese yuan, and the consequent hollowing out of Japanese industries. ${ }^{50}$

Against this backdrop, Japanese subsidiaries in China today play a vital role in the development of China's foreign trade, as most of their output is exported to Japan and thirdparty countries. In this sense, FDI in China has been a critical factor in boosting intra-regional trade in East Asia.

Japanese trading strategy has undergone a shift from that of selling finished goods to the Chinese domestic market to a series of activities concerned with 'processing trade', i.e. exporting parts and components to China, processing and assembling the finished goods in China, and then re-exporting them to Japan and third countries, using China as an export 
platform for the global market. According to Dean et al. in 2007, 56.6 percent of China's exports to Japan were processing exports. ${ }^{51}$

As a result, trade patterns in East Asia have changed, with an increase in intra-regional and intra-industry trade and a shift in the commodity structure of trade from final to intermediate goods. ${ }^{52}$ Ando ${ }^{53}$ shows that the importance of intra-industry trade has increased sharply for machinery trade in general, but especially so in the case of the vertical intra-industry trade of machinery parts and components, whose share of the total trade in machinery parts and components rose from 18 percent in 1990 to 81 percent in 2000 for China and from 38 percent to 69 percent for Japan. ${ }^{54}$ This increase was due in the main to the international fragmentation of the production processes occurring primarily through foreign-invested enterprises (FIEs). ${ }^{55}$ In 2007, Japanese FIEs accounted for 86.9 percent of processing exports to Japan. ${ }^{56}$

As Japanese subsidiaries in China increase their local content, they also share industrial infrastructure with local firms, integrating production chains with the participation of the Chinese labor force in labor-intensive segments of high added-value manufactured products, thereby improving productivity and efficiency in the local Chinese manufacturing industry. At the same time, intra-firm trade between Japanese parent firms and their affiliates in China greatly contributes to the intra-industry trade of the two economies. Moreover, Japanese FDI in China helps to create jobs, increase exports from China and transfer technology and knowhow to local Chinese firms, thus upgrading China's industrial and trade structure and allowing China to use global marketing networks and Japanese brand names to sell made-in-China products on the global market.

While external Chinese demand has certainly been crucial in preventing the Japanese economy from slumping into another recession, the Chinese economy is also taking advantage of Japanese FDI, made up of a package of capital, technology and know-how. China is in the middle of a global production chain, with Japan as the principal source of imported intermediates, most of which are processing intermediates.

Japan and China share great mutual economic interests, in terms of both trade and investment, and Japanese FIEs play an important role in the global production chain. Japan is critical in helping Chinese industry improve its industrial capacity, productive variety and 
productivity and, given that FDI is more stable than trade, Japan and China's economic interdependence has also become much stronger.

\section{Analysis of Japan's Hedging Strategy Towards China}

As indicated in the earlier theoretical discussion, the empirical evidence casts doubts on neorealist tenets and shows that small and middle powers are not limited to pursuing either pure balancing or pure bandwagoning strategies, but, rather, they tend to adopt a "middle position", referred to by many as a "hedging strategy". As outlined in section 2, it is our firm belief that Kuik's concept of hedging can be used to describe Japanese policy towards China. In section 3 we have seen how a combination of domestic and international factors led to a gradual shift away from the "friendship diplomacy" of the 1970s and 1980s to a new paradigm that is best understood in the light of Kuik's model. As such, Japan finds itself today in a new phase of what has been labeled as "competitive engagement with a hard balance", ${ }^{57}$ although we consider it best described as a "hedging strategy" with elements of economic pragmatism, binding-engagement, dominance-denial and indirect balancing. ${ }^{58}$

First of all, by adhering to a sort of economic-pragmatism, or a "business first" approach, Japan has attempted to maximize its economic interdependence with China through trade and investment, in spite of its political and security concerns. Tokyo has instigated a clearly pragmatic policy with China in the economic realm. Although Japan terminated its yen programs with China in 2008, Tokyo obviously favors promoting economic interdependence with China, and nowhere is this truer than in its trade and investment policies. As reported in section 3, in 2013 Japanese trade with China accounted for 20\% of the total of Japan's imports and exports, confirming China as Japan's largest trading partner.

Japan experienced a marked increase in its processing trade to China following the latter's accession to the WTO, with Japan establishing itself as a key source of parts and components for China in the global supply chain. According to Dean et al., ${ }^{59}$ about $74 \%$ of Chinese imports from Japan were intermediate goods, and nearly half of these intermediate 
goods from Japan came to China under the processing trade regime, meaning that they were re-exported after processing. This in turn demonstrates both the importance of Japan in China's global supply chain - as the main source of China's imported intermediate goods - and the importance of vertical integration between Japanese and Chinese industries. Moreover, Japan has become the second largest source of FDI in China. Japanese FIEs are unquestionably the main vehicle for China's integration in the global supply chain, as they account for the largest share of exports and most of its processing trade. As stated by Wan, "Jopan wants China to grow, and China wants to see Japan recover quickly economically; the alternatives would hurt their national interests".

Secondly, Japan has pursued a strategy of binding-engagement in order to establish bilateral and multilateral channels of institutionalized communication to 'socialize' the superpower, to use the constructivists' expression. As Ciorciari ${ }^{61}$ states, in the post-Cold War period the reduction in ideological hostility and the liberalization of the economic order, together with the subsequent establishment of new diplomatic forums, have provided the opportunity for strengthening these channels of communication. Whether or not these institutions are mere "talk shops" (as the realists would assert), a sort of "soft" regional and interregional dialogue has emerged between Japan and China, including the ASEAN Regional Forum (ARF), ${ }^{62}$ the Japan-China Security Dialogue (from 1993 onward), the Japan-China Counter-Terrorism Consultations (2011), the Japan-China High Level Consultation on Maritime Affairs (2012) and ASEAN+3 and various economic forums including the East Asia Summit, Asia-Pacific Economic Cooperation (APEC), Asia Europe Meeting (ASEM), ASEAN+6, ASEAN+8, the East Asia Summit (EAS), the Forum of East Asia-Latin America and the Round of Negotiations on a Free Trade Agreement between Japan, China and South Korea.

For Japan, binding China to the main regional and international institutions, as well as creating predictable channels of communication, is a way of involving China in Western international regimes and of promoting its role as a "responsible stakeholder". As discussed, following the Tiananmen Square incident Japan pursued a clear policy of engagement in order to induce China to behave benignly and to bring it back into the international community. In 
the same vein, China's accession to the WTO represented not only a considerable boost to trade and investment, but also the acceptance of the rules and norms of international trade, ultimately making China a more predictable and reliable power in the economic realm. Other relevant examples of binding-engagement are provided by ASEAN +3 and the EAS where the Chinese and the Japanese governments have taken a range of initiatives aimed at discussing specific issues, including energy efficiency, oil stockpiling and confidence-building measures on fishing rules. ${ }^{63}$

Kuik argues that binding-engagement and dominance-denial are, in a way, two sides of the same coin. Accordingly, Japan has, in third place, adopted a visible dominance-denial attitude, seeking not only to involve other powers in persuading China to be engaged and to behave in a benign way, but also to prevent the emergence of a regionally and globally dominant China by involving other countries in the Asian-Pacific regional architecture. Tokyo's enmeshment in this regional architecture can be explained not only in terms of its willingness to bandwagon with the most dynamic region in the world and of its efforts to have a foreign policy that is more independent of the United States, but also in terms of its attempts to counter the rise of China.

Since Japan cannot solve the systemic problem of China's rise on its own, it has involved powers that are not strictly located in East Asia, including the United States, India, Australia and New Zealand, countries that Japan considers as forming an "arc of freedom and prosperity" ${ }^{64}$ Following a more assertive attitude from China after the 2008 financial crisis, South-East Asian countries are also greatly concerned by China's rise, and have sought indirectly to counterbalance China's assertiveness towards the United States and Japan.

One of the most prominent examples of this strategy in the recent period has been the establishment of the Trans-Pacific Partnership (TPP), a mega-regional free trade agreement concerned not only with tariff reductions but also with rewriting the rules of international trade. The TPP was signed by 12 Pacific Rim countries, including the United States, Japan, Mexico, Vietnam and Australia, but it intentionally excludes China. Although China was invited by the United States to join negotiations in 2012, more recently the Obama administration has explicitly excluded China on the grounds that it cannot meet the high standards agreed to in the 
Treaty. However, the exclusion of China from the TPP should also be seen as part of a Japanese-American strategy to contain the increasing economic and political power of China in the Asia-Pacific region. ${ }^{65}$

As a reaction to US-Japanese attempts to avoid any dominance of China in Asian regionalism, Beijing has taken a two-track approach: while it participates in such institutions as the IMF, the World Bank, the WTO and the ADB, at the same time it seeks to promote the importance of alternative institutions. These include the Regional Comprehensive Economic Partnership (an ASEAN+6 proposal for the Asian Pacific, including Japan, India and South Korea), an alternative free trade agreement to that of the TPP, the Asian Infrastructure Investment Bank, and the Belt and Road Initiative, an alternative to the United States' Asia Pivot strategy.

Finally, Japan is pursuing a strategy of indirect balancing against China in the field of security or a "just-in-case" strategy. Given the uncertainties about China's actual intentions, Japan has made preparations for the worst-case scenario: a hostile hegemonic China. Although none of the documents on foreign policy (NDPO, Araki Report, SCC, etc.) describe China in hostile terms, Japan is concerned about episodes of ongoing friction with the country. As discussed in section 3, China's Law of the Territorial Sea (which intimates that it might use force to assert its claims over Senkaku), Chinese nuclear testing, Chinese military exercises in the Taiwan Straits, various incidents involving Chinese vessels and the Japanese Coast Guard, incursions by Chinese submarines into Japanese territorial waters in Ryuku and the strengthening and modernization of its military power throughout the 1990s are especially disquieting for strategists in Tokyo.

In response, Japan's strategy has been to increase its own military capabilities and to strengthen its security alliance with the United States, without however identifying China as a direct threat. As for its indirect internal balancing, Japan has made clear in its official documents that the recent acquisition of a new ballistic missile defense system, ${ }^{66}$ the Sea-Based Midcourse Defense (SMD) system, Patriot Advanced Capability-3, and the modernization of its Self-Defense Forces should be understood as a means of protecting the country and it citizens against possible threats of terrorism and from the North Korean regime. Nevertheless, 
these measures must also be seen as a response to China's rise in military power. Under Abe, Japan has created a new National Security Council to coordinate its foreign and security policy and it has updated its National Security Strategy and released new National Defense Program Guidelines (2013).

As for its external balancing, Japan has strengthened its alliance with the United States thanks to the Joint Security Declaration signed by Hashimoto and Clinton, the new Defense Cooperation Guidelines (1997), the October 2000 Armitage Report, Koizumi's Seven Point Plan to support the American fight against terrorism (September 2001), the Basic Self-Defense Forces Plan to enable the sending of the SDF into the Indian Ocean (November 2001), the Special Measures Law for Humanitarian and Reconstruction Assistance in Iraq (July 2003), and the report issued by the Araki Commission (October, 2004). All these measures are evidence of Japan's external balancing against the rise of China, a strategy that has recently been confirmed under the US's "pivot to Asia" program. In line with Obama's "rebalancing" strategy, over the last four years Abe Shinzo has issued a new Mid-Term Defense Plan aimed at increasing interoperability with US forces and Japan has participated with the US in the procurement of the V-22 Osprey aircraft, a Joint Strike Strategy, and SM-3 Missiles. One of Abe's most recent measures has been the controversial reinterpretation of the Constitution, recognizing Japan's right to collective self-defense, that is, to make a greater contribution to the US's regional and global strategy.

\section{Conclusions}

This article has argued that the Japanese response to China's rise cannot be adequately explained in terms of realist or liberal traditions alone. First, realism fails to provide sufficient coverage of the vast array of strategies available to a nation when seeking to deal with a rising power. Realist tenets are, therefore, overly simplistic in their claim that, when faced with a rising power, states are likely to opt for either internal and external balancing or bandwagoning. Were this to be true, Japan would surely have become a great power with its own nuclear 
capability and massive conventional forces, something that is eminently not the case. Most of the realist literature, besides confusing the concept of the normalization of Japanese foreign policy with the concept of militarism, fails to take into consideration the many brakes operating within Japanese society, including its aversion to militarism, the long-held norm of pacifism, the obstacles to amending the Japanese constitution and the need to obtain a qualified majority in the National Diet to do so.

Second, realism assumes that Japan will pursue a cooperative strategy to induce benign intentions on the part of China while simultaneously strengthening the Japanese-American security treaty in the face of a future threat from China. Likewise, Japan is expected to foster its alliance with the US by becoming less of a "buck-passer" and, so, reducing the danger of abandonment by Washington. Nevertheless, as has been pointed out, from the perspective of offensive realism such action could result in China seeing this stronger alliance as a means of containing them, and so it could intensify the "security dilemma" between the two neighboring countries. Addressing the potential problem of US abandonment in the "alliance dilemma" could increase the classic "security dilemma". In short, it is far from easy for Japan to pursue a cooperative strategy toward a rising China, and realists do not really offer a feasible explanation.

Meanwhile, liberal traditions consider that cooperation in IR results from common vested interests in such issues as trade and economic interdependence. For liberals, it is not that actors are not selfish; on the contrary, it is the logic of collective action that allows them to achieve a win-win situation. Therefore, given Japan and China's enormous economic interdependence, in liberal eyes the relationship between the two countries should be very robust. However, as this article has demonstrated, relations in the political and security spheres have not only worsened, but over the last few years a number of past episodes have reemerged, including the revision of history textbooks, and the disputes over the Senkaku Islands and the EEZ.

The main argument of this article, therefore, is that some middle powers adopt policies that differ quite markedly from pure forms of balancing and bandwagoning. Instead, they seek to take a "middle" course that might be labeled a "hedging strategy". Thus, Japan is pursuing 
a cooperative strategy vis-à-vis China aimed at fostering its benign intentions, but at the same time it is hedging against the possible failure of such engagement by strengthening its alliance with the US and bolstering its military force. As outlined in section 4, over the last 20 years Tokyo has been pursuing what Kuik calls pure hedging. If we take recent events into consideration, what is clear is that Japan's foreign policy adheres closely to Kuik's hedging model, as opposed to what Hornung understands as a hedging strategy. Japan is not powerful enough to balance against the rise of China, yet it is too strong to simply bandwagon with China. For Japan, hedging represents not only a means for offsetting risk in an uncertain world, but it is also the natural position of a strong actor with great capabilities. As a middle power, Japan tends to hedge, seeking to take advantage of its engagement strategy toward China via economic cooperation and growing interdependence.

The rise of China has drastically changed Japan's trading patterns and industrial structure. Today, China is Japan's main trading partner in terms of total trade, and Chinese imports to Japan have grown steadily over the century. At the same time, China has emerged as one of the leading destinations of Japanese FDI, and Japanese FIEs play an important role in its global production chain. Japanese subsidiaries are the main actors of the "processing trade", using China as both a processing and assembly platform, before exporting the finished products to Japan and third countries. In this process two features stand out: first that Japan is the main source of China's imported intermediate goods and, second, the vertical integration between Japanese and Chinese industries is of great importance.

While external Chinese demand has been critical for the survival of the Japanese economy, Japanese subsidiaries in China help to create jobs, boost exports from China and transfer technology and know-how to local Chinese firms, improving the country's industrial capacity, productive variety and productivity. Since FDI is more stable and more permanent than trade, Japan and China's economic interdependence has become much stronger.

Japan has also opened up channels of communication with China via a number of regional and interregional dialogues, including the Japan-China Security Dialogue, ASEM and ASEAN +3 , with the aim of socializing China and making its neighbor a more responsible stakeholder. However, Japan is also hedging against the possible threat that China might come 
to pose in the future not only by seeking to thwart Chinese attempts to dominate regionally and globally, but also by bolstering its Self-Defense Forces (internal balancing) and by expanding its security alliance with the US (external balancing). Today, Tokyo provides support to its allies (the United States), gives demonstrations of its power to its enemies (North Korea), and proposes neutrality to its likely adversaries (China).

Finally, one last question needs to be addressed in our analysis of hedging: What factors will determine Japan's long term action vis-à-vis China? We assume a priori that these determinants will be a combination of national (domestic restructuring and leader-driven) and international factors (external shocks or beiatsu). However, it seems that three factors are likely to determine whether the current tendency to pursue a hedging strategy will be reverted in the future (i.e. pursuing bandwagoning or balancing strategies): the immediacy of a real threat, the existence of ideological fault-lines, and the existence of an all-out great power rivalry between the rising power (China) and the dominant power (the United States).$^{67}$ As soon as one of these factors emerges, hedging will no longer be possible.

\footnotetext{
${ }^{1}$ Yoshihide Soeya, Masayuki Tadokoro, David A. Welch, eds., Japan as a «normal country»?: a nation in search of its place in the world (Toronto and Buffalo: University of Toronto Press, 2011).

${ }^{2}$ Cheng-Chwee Kuik, "The Essence of Hedging: Malaysia and Singapore's Response to a Rising China," Contemporary Southeast Asia Vol. 30, No. 2, pp.-159-85 (2008).

${ }^{3}$ See Daniel Roy, "Southeast Asia and China: Balancing or Bandwagoning?," Contemporary Southeast Asia Vol. 27, No. 2, pp. 305-22 (2005) and Jeffrey J. Hornung, "Japan's Growing Hard Hedge Against China," Asian Security Vol. 10, No. 2, pp. 97-122 (2014).

${ }^{4}$ John Mearsheimer, The Tragedy of Great Power Politics (New York: W.W. Norton and Company, 2001), p. 31 .

${ }^{5}$ Kenneth N. Waltz, “The Emerging Structure of International Politics," International Security Vol. 18, No. 2, pp. $44-79$ (1993).

${ }^{6}$ John Mearsheimer, The Tragedy of Great Power Politics, p. 3.

${ }^{7}$ John Mearsheimer, The Tragedy of Great Power Politics, p. 163.

${ }^{8}$ Barry Buzan, "China in international society: is "peaceful rise" possible?," The Chinese Journal of International Politics Vol. 3, No. 1, p. 1 (2010).

9 See Michael Desch "Culture Clash: Assessing the Importance of Ideas in Security Studies," International Security Vol. 23, No. 1, pp. 141-70 (1998); John Mearsheimer, The Tragedy of Great Power Politics, and Kenneth N. Waltz, "The Emerging Structure of International Politics,"International Security Vol. 18, No. 2, pp. 44-79 (1993).
} 
${ }^{10}$ A highly rigid amendment procedure makes changes to the Japanese constitution very unlikely - first, it would require a two-thirds majority in the National Diet and, second, the majority of Japanese citizens would have to agree to the removal of Article 9 from the constitution.

${ }^{11}$ Available at http://www.yomiuri.co.jp/feature/TO000302.

12 Paul Midford, “The Logic of Reassurance and Japan’s Grand Strategy”, Security Studies Vol. 11, No. 3, pp.1-43 (2002).

${ }^{13}$ David Edelstein, "Managing uncertainty: Beliefs about intentions and the rise of great powers," Security Studies Vol. 12, No. 1, pp. 1-40 (2002).

${ }^{14}$ Cheng-Chwee Kuik, “The Essence of Hedging,” pp. 159-85.

${ }^{15}$ Eric Heginbotham, Richard J. Samuels, “Japan's Dual Hedge," Foreign Affairs Vol. 81, No.5, pp.110-21 (2002); Denny Roy, "Southeast Asia and China: Balancing or Bandwagoning?," Contemporary Southeast Asia Vol. 27, No.2, pp. 305-22 (2005); Cheng-Chwee Kuik, "The Essence of Hedging"; Jun Tsunekawa, "The Rise of China: Responses from Southeast Asia and Japan," The National Institute for Defense Studies (2009); Ken Jimbo, “Japan's Security Strategy Toward China: Integration, Balancing and Deterrence in the Era of Power Shift," The Tokyo Foundation (2011);Yasuhiro Matsuda, "Engagement and Hedging: Japan's Strategy toward China," SAIS Review of International Affairs Vol. 32, No. 2, pp. 109-19 (Summer-Fall 2014); Corey J, Wallace, “Japan's strategic pivot south: diversifying the dual hedge," International Relations of the Asia-Pacific Vol. 13, No. 3, pp. $479-517$ (2014); Van Jackson, "Power, Trust, and Network Complexity: Three Logics of Hedging in Asian Security," International Relations of the Asia-Pacific Vol. 14, No. 3, pp. 331-56 (2014); Narushige Michishita, and Richard J.Samuels, "Hugging and Hedging: Japanese Grand Strategy in the Twenty-First Century," in Henry R. Nau, and Deepa M. Ollapally, eds., World views of Aspiring powers. Domestic Foreign Policy Debates in China, India, Iran, Japan, and Russia (Oxford: Oxford University Press, 2014) and Jeffrey J. Hornung, "Japan's Growing Hard Hedge Against China," Asian Security Vol. 10, No. 2, pp. 97-122 (2014).

16 Denny Roy, “Southeast Asia and China: Balancing or Bandwagoning?," p. 306.

${ }^{17}$ Jeffrey J. Hornung, “Japan's Growing Hard Hedge Against China,” p.99.

${ }^{18}$ Kenneth N, Waltz, Theory of International Politics (Reading: Addison-wesley, 1979) and Stephen M. Walt, Origins of Alliances (Ithaca and London: Cornell University Press, 1987).

${ }^{19}$ Richard L. Schweller, "Bandwagoning for Profit: Bringing the Revisionist State Back," International Security Vol. 19, No. 1, pp. 72-107 (1994).

${ }^{20}$ Cheng-Chwee Kuik, “The Essence of Hedging,” p. 167.

${ }^{21}$ Cheng-Chwee Kuik, “The Essence of Hedging,” p.171.

${ }^{22}$ Bernard Wood, "Middle Powers in the International System: A Preliminary Assessment of Potential," Wider Working Paper Vol. 11, pp. 1-44 (1987).

${ }^{23}$ Eduard Jordaan, "The Concept of a Middle Power in International Relations: Distinguishing between Emerging and Traditional Middle Powers,” Politikon Vol. 30, No. 1, pp. 165-81 (2003).

${ }^{24}$ Yoshihide Soeya, 日本の「ミドルパワー」外交[Japan's middle power diplomacy] Tokyo: Chikuma Shobo, 2005).

25 Yoshihide Soeya, Japan's Economic Diplomacy with China, 1945-1978, (Oxford: Clarendon Press, 1998).

${ }^{26}$ Hitoshi Tanaka, “Japan and China at a Crossroads," East Asia Insights. Toward Community Building Vol. 1, No. 2 (March 2006). 
${ }^{27}$ Yoshimitsu Nishikawa, 日本の外交政策。現状と課題、展望［Japan’s Foreign Policy: Then, now and future], (Tokyo: Gakubunsha, 2004), p.106.

${ }^{28}$ Hidenori Ijiri, "Sino-Japanese Controversy since the 1972 Diplomatic Normalization," The China Quarterly Vol. 124, p. 643 (1990).

${ }^{29}$ Although Western countries including Japan imposed sanctions on China after the Tiananmen massacre in 1989, Japan soon wanted to bring China back into the international community. Thus, it restored yen loans to China in 1990 and resumed relations with China even after economic sanctions had been imposed by Western democracies to protest against human rights violations. Moreover, Emperor Akihito visited China in October 1992. For further details, see Green, M. and Self, B., 1996. “Japan's Changing China Policy: From Commercial Liberalism to Reluctant Realism”, Survival Vol. 38 , No. 2, pp. 35-58.

30 In 1992, the Chinese government approved a law stating that any claim over territorial disputes could be resolved by the use of force. As is repeated in various places in the act, the Government of the People's Republic of China has the right to take all necessary measures to prevent and stop non-innocent passage through its territorial seas. See the original text at http://www.asianlii.org/cn/ blegis/cen/laws/lotprocottsatcz739/

${ }^{31}$ See Japan Times, September 29, 2013.

http://www.japantimes.co.jp/news/2013/09/24/national/transcript-of-caroline-kennedys-senatehearing/\#.VREh0ZOG-Z9

${ }^{32}$ Christopher W. Hughes, Japan's Remilitarization (London: Routledge, 2009).

${ }^{33}$ The Japanese Coast Guard (Kaijō Hoan-chō) was created in 2000 and its main goals are to ensure safety and order at sea, to act in self-defense or in case of emergency. The Coast Guard can use fire power to combat maritime intrusions, as occurred with the so-called North Korean and Chinese fushinsen, or ships suspected of espionage.

${ }^{34}$ When pursuing the indirect-balancing option, a country seeks to balance internally and externally the power of a rising power without directly identifying it as a military threat. The strategy aims at forging alliances with other powers while modernizing defense capabilities, but without specifically targeting the rising power. While pure balancing strategies constitute a clear military policy of containment against a specific threat, a state adopting an indirect balancing strategy is acting in case an uncertain situation arises. China is considered a possible threat by the Japanese Government, but it has never been identified as such in order not to antagonize the rising power.

${ }^{35}$ Weston S. Konishi W. S. From Rhetoric to Reality: Foreign Policy Making under the Democratic Party of Japan (Institute for Foreign Policy Analysis, 2014).

${ }^{36}$ Michael J. Green and Jeffrey W. Hornung, “Ten Myths about Japan's Collective Self-Defense Change: What the Critics Don't Understand about Japan's Constitutional Reinterpretation,” The Diplomat (July 10, 2014).

${ }^{37}$ For example, in 1990, the leading Chinese exports to Japan were miscellaneous manufactured products $(27.5 \%)$, fuels consisting primarily of crude oil (24\%) and food and live animals (15.7\%), while the main Japanese exports to China were machinery and transport equipment (44\%) and manufactured goods (32\%).

${ }^{38}$ Yuqing Xing, "Japan's Unique Economic Relations with China: Economic Integration Under Political Uncertainty,” East Asian Institute Vol. 410, No. 23 (2008).

${ }^{39}$ The Chinese procurement boom was a period characterized by an extraordinary increase in all kinds of imports to China following its accession to the WTO and because of the country's high rate of economic growth.

${ }^{40}$ Jeffrey J. Hornung, "Japan's Growing Hard Hedge Against China,"

${ }^{41}$ JETRO, 2012 JETRO Global Trade and Investment Report (Tokyo, Japan External Trade 
Organization, 2012). Available at https://www.jetro.go.jp/en/reports/white_paper/trade_invest 2012 overview.pdf

${ }^{42}$ Ministry of Internal Affairs and Communications (Hereafter MIC), Foreign Trade, Balance of Payments and International Cooperation. Table 6-1,(Tokyo, Statistics Bureau). Available at http://www.stat.go.jp/english/data/nenkan/1431-06.htm

${ }^{43}$ Statistical Handbook of Japan, (2014), Trade, International Balance of Payments, and International Cooperation, MIC, (Tokyo, Statistics Bureau, 2014) pp 108-123. Available at http://www.stat.go .jp/english/data/handbook/index.htm

${ }^{44}$ Bank of Japan, Outward/Inward Direct Investment by Region and Industry (2005-2013, Balance of Payments Statistics. Available at http://www.boj.or.jp/en/statistics/br/bop/index.htm/

${ }^{45}$ Jeffrey J. Hornung, "Japan's Growing Hard Hedge Against China,"

${ }^{46}$ JETRO, 2014 JETRO Global Trade and Investment Report (JETRO, 2014). Available at http://www. jetro.go.jp/en/reports/white_paper/trade_invest_2014_overview.pdf

47 JETRO, 2013 JETRO Global Trade and Investment Report (JETRO, 2013). Available at http://www.jetro.go.jp/ext_images/en/reports/white_paper/trade_invest_2013 overview.pdf

${ }^{48}$ JETRO, 2013 JETRO Global Trade and Investment Report (JETRO, 2013).

${ }^{49}$ Yuqing Xing, “Japan's Unique Economic Relations with China”.

${ }^{50}$ Hideo Ohashi "The Rise of China: Challenges and opportunities to the Japanese Economy" in Herbert S. Yee, ed; China's Rise: Threat or Opportunity? (London and New York: Routledge, 2004) pp. 13447.

${ }^{51}$ Judith M. Dean, Lovely, Mary E. and Jesse Mora, "Decomposing China-Japan-U.S. Trade: Vertical Specialization, Ownership, and Organizational Form," Journal of Asian Economics Vol. 20, No. 6, pp. 596-610 (2009).

${ }^{52}$ Hideo Ohashi "The Rise of China: Challenges and opportunities to the Japanese Economy"

${ }^{53}$ Mitsuyo Ando, "Fragmentation and Vertical intra-industry Trade is East Asia," North American Journal of Economics and Finance Vol. 17, pp. 257-81 (2006).

${ }^{54}$ Vertical intra-industry trade occurs when two countries with different income distributions have different factor endowments or different technologies in a product sector. The higher- (lower-) quality variety is produced by the higher- (lower-) income country, with a higher (lower) capital-labor ratio, technology and a higher (lower) price (Ando, 2006).

${ }^{55}$ International fragmentation of the production process refers to the international division of a product process into two or more production blocks.

${ }^{56}$ Judith M. Dean, Lovely, Mary E. and Jesse Mora, “Decomposing China,” pp. 596-610.

${ }^{57}$ Mike M. Mochizuki, "Japan's Shifting Strategy toward the Rise of China”, The Journal of Strategic Studies Vol. 30, No. 4-5, pp. 739-76 (2007).

${ }^{58}$ Reinhardt Drifte uses the term 'engagement' to describe a policy based on providing China with economic and political incentives, and the term 'hedging' to refer to internal and external military balancing (Drifte, 2003:1-11). However, considering the broad misunderstanding of engagement policies among liberals, realists, and constructivists, we have opted to use the term 'hedging'. See Reinhard Drifte, Japan's security relations with China since 1989: from balancing to bandwagoning? (London: Routledge, 2003)

${ }^{59}$ Judith M. Dean, Lovely, Mary E. and Jesse Mora, “Decomposing China,” pp. 596-610.

${ }^{60}$ Ming Wan, "Sino-Japanese relations: interaction3bgic, and transformation," (Stanford: Stanford 
University Press, 2006) p.215.

${ }^{61}$ John D. Ciorciari, "The balance of great-power influence in contemporary Southeast Asia," International Relations of the Asia-Pacific Vol. 9, No.1, pp. 157-96. (2009).

${ }^{62}$ Although the ARF is not considered a security arrangement per se, it does provide a forum for discussing specific regional disputes with the aim of maintain peace in the region using non-traditional military measures, including consensus diplomacy and confidence building.

${ }^{63}$ Yoshimitsu Hidetaka, "Sino-Japanese Relations and Cooperative Institutions in Energy", Working Paper Series, Vol. 2011-07, pp. 1-34 (2011).

${ }^{64}$ See Taro Aso, "Arc of Freedom and Prosperity: Japan's Expanding Diplomatic Horizons". Speech to the Japan Institute of International Affairs, Tokyo, November 30th, 2006.

${ }^{65}$ Ann Capling and John Ravenhill, "The TPP: Multilateralizing Regionalism or the securitization of trade policy?," Paper presented at the ISA Conference, San Diego, California (2012).

${ }^{66}$ Although the official stance is that the ballistic defense system was acquired to defend Japan against a possible attack from North Korea, as security specialists interviewed in Japan in $2010 \mathrm{affirm}$, a missile defense system could also be used in case of attack to fight back and, what is worse for China, to defend Taiwan against a possible attack from China. The same can be said about the SMD system, the Patriot Advanced Capability. Although the official aim of this system is to repel any attack from outside, some specialists point to China as the main object for Japanese missile system.

${ }^{67}$ Cheng-Chwee Kuik, "The Essence of Hedging," p. 165.

Table 1: Japan's hedging strategies according to Kuik

\begin{tabular}{|c|c|c|c|c|c|c|}
\hline \multirow{3}{*}{$\begin{array}{l}\text { Balancing } \\
\text { strategy } \\
\text { (pure form) }\end{array}$} & \multicolumn{5}{|c|}{ HEDGING STRATEGY } & \multirow{3}{*}{$\begin{array}{l}\text { Bandwa- } \\
\text { goning } \\
\text { strategy } \\
\text { (pure } \\
\text { form) }\end{array}$} \\
\hline & \multicolumn{2}{|c|}{ Risk-Contingency Options } & \multicolumn{3}{|c|}{ Return-Maximizing Options } & \\
\hline & $\begin{array}{l}\text { Indirect } \\
\text { Balancing }\end{array}$ & $\begin{array}{l}\text { Dominance- } \\
\text { Denial }\end{array}$ & $\begin{array}{l}\text { Economic- } \\
\text { Pragmatism }\end{array}$ & $\begin{array}{l}\text { Binding } \\
\text { Engagement }\end{array}$ & $\begin{array}{l}\text { Limited } \\
\text { Bandwagonin } \\
\mathrm{g}\end{array}$ & \\
\hline
\end{tabular}

Source: Based on Kuik, 2008

Table 2: Japanese outward direct investment

(Net flows per hundred million yen) 


\begin{tabular}{|l|l|l|l|l|l|}
\hline & 2009 & 2010 & 2011 & 2012 & 2013 \\
\hline World & 69.896 & 49.388 & 85.872 & 97.782 & 132.485 \\
\hline Asia & 19.427 & 19.035 & 31.209 & 26.778 & 39.775 \\
\hline China & 6.492 & 6.284 & 10.046 & 10.759 & 8.870 \\
\hline ASEAN & 6.587 & 7.710 & 15.491 & 8.586 & 23.331 \\
\hline North America & 10.207 & 7.810 & 11.879 & 28.629 & 45.730 \\
\hline U.S.A. & 9.989 & 7.968 & 11.530 & 25.609 & 42.964 \\
\hline Europe & 16.680 & 12.781 & 31.437 & 24.748 & 31.596 \\
\hline
\end{tabular}

Source: Balance of Payment Statistics (Bank of Japan) 